\title{
Career-Oriented Performance Tasks in Chemistry: Effects on Students' Critical Thinking Skills
}

\author{
Allen A. Espinosa, ${ }^{1}$ Sheryl Lyn C. Monterola, ${ }^{2}$ and Amelia E. Punzalan ${ }^{3}$ \\ ${ }^{1}$ Department of Physical Sciences, College of Science, Philippine Normal University, 1000 Manila, Philippines \\ ${ }^{2}$ Division of Curriculum and Instruction, College of Education, University of the Philippines, \\ 1101 Diliman, Philippines \\ ${ }^{3}$ National Institute for Science and Mathematics Education Development, University of the Philippines, \\ 1101 Diliman, Philippines
}

Correspondence should be addressed to Allen A. Espinosa; allen10518@gmail.com

Received 15 April 2013; Revised 30 April 2013; Accepted 7 May 2013

Academic Editor: Eric Z. F. Liu

Copyright (C) 2013 Allen A. Espinosa et al. This is an open access article distributed under the Creative Commons Attribution License, which permits unrestricted use, distribution, and reproduction in any medium, provided the original work is properly cited.

\begin{abstract}
The study was conducted to assess the effectiveness of career-oriented performance task (COPT) approach against the traditional teaching approach (TTA) in enhancing students' critical thinking skills. Specifically, it sought to find out if students exposed to COPT have higher critical thinking skills than those students exposed to the traditional teaching approach (TTA). COPT approach aims to integrate career-oriented examples and inquiry-based activities in general inorganic chemistry. The study used the quasiexperimental pretest-posttest control group design. The sample of the study consisted of two (2) intact sections of first-year students in a private higher education institution in Manila who are enrolled in general inorganic chemistry during the second semester of school year 2011-2012. Thirty-nine (39) students are in the COPT class while thirty-eight (38) students are in the TTA class. The instrument used in the study is the Watson-Glaser Critical Thinking Appraisal (WGCTA) to evaluate students' critical thinking skills. The study found out that the mean posttest score in the WGCTA was not significantly higher for students exposed to COPT than for students exposed to TTA. The COPT approach in teaching chemistry was not effective in enhancing students' critical thinking skills given the limited time of intervention. Longer exposure to intervention is necessary to enhance students' critical thinking skills.
\end{abstract}

\section{Background of the Study}

In the Philippines, results of the national achievement test in secondary science were reported to be $51.8 \%$ in 2007 and $57.8 \%$ in 2008. Although there has been an evident increase in students' mastery level of six percentage points, it is still far from the government's target criterion level, which is $75 \%$ [1] Moreover, out of 45 participating countries in the Trends in International Mathematics and Science Study (TIMSS) in 2003, the Philippines ranked 41st and 42nd in mathematics and science, respectively. This suggests that Filipino students are weak in terms of mastery level in mathematics and science when they graduate from high school [2]. Specifically, in chemistry, Filipino students have 30\% average correct answers in TIMSS which is way below the international average of $45 \%$ correct answers.

One of the most relevant skills in science learning is student's critical thinking skills. Critical thinking skills are those requiring students to apply information in new situations and in solving problems. Critical thinking is an intellectually disciplined process that is characterized by creative conceptualization, application, analysis, synthesis, and evaluation of information collected from the observations and experiences as a guide to belief and action [3]. In its exemplary form, it is based on universal intellectual values that transcend subject matter divisions: clarity, accuracy, precision, consistency, relevance, sound evidence, good reasons, depth, breadth, and fairness. Elder [4] offered a simplified operational definition 
TABLE 1: Comparison between traditional instruction and performance-based learning tasks.

\begin{tabular}{ll}
\hline $\begin{array}{l}\text { Traditional instructional } \\
\text { tasks }\end{array}$ & $\begin{array}{l}\text { Performance-based learning } \\
\text { tasks }\end{array}$ \\
\hline (i) Define & (i) Classify \\
(ii) Remember & (ii) Compare \\
(iii) List & (iii) Evaluate \\
\hline
\end{tabular}

of critical thinking, that is, as a self-guided, "self-disciplined thinking which attempts to reason at the highest level of quality in a fair-minded way".

From the experience and observations of the researcher, it appeared that chemistry students start classes with many expectations, questions, and great interest that are not sustained because they find the subject too abstract and mathematical; therefore, it requires a special way of thinking to be able to learn it. According to Brickhouse and Carter [5], students tend to view chemistry to be very cumulative, because one gets lost if he/she misses an idea. Other barriers to chemistry achievement are based on the instruction aspect or how the subject is taught, for example, nonimplementation of inquiry-oriented teaching methods and of technologyintegrated approach. It has been shown that activity-based approaches significantly enhance students' critical thinking and scientific attitudes [6].

Thus, it is imperative to change students' perception about chemistry and the way the subject is taught in order to improve performance in the subject. This can be achieved by making chemistry more relevant to the students' realm of experience and by integrating inquiry activities in the teaching of the subject. The National Academy of Science [7] challenged chemistry teachers to connect the subject to everyday experiences through professional career development that focuses on valuable linkages to related fields.

A study done by Barrow and Phillips [8] has shown that career-oriented activities in the residential summer program of the New Experiences for Women in Science and Technology, otherwise known as The NEWTON Academy, positively increased students' interest in pursuing a career in physics, engineering, and mathematics. Their experience in the summer program resulted in good performance both in their physics and mathematics classes. Moreover, House [9] found out from his study that career-oriented classroom instructional activities do not only increase the interest in science career among students in Korea but also increased the interest in participating in daily science classes.

This study proposes an intervention called career-oriented performance task (COPT), which aims to integrate career-oriented examples and inquiry-based activities in general inorganic chemistry to improve students' critical thinking skills. General inorganic chemistry is chosen instead of other chemistry subjects since this is a general education course, meaning, most if not all collegiate students are taking this course. At the end of the semester, the students are not expected to remember all the concepts learned, but at least they have developed or improved their critical thinking skills through the intervention.
The study addressed the following question: do students exposed to COPT have higher critical thinking skills than those students exposed to the traditional teaching approach (TTA)?

\section{Career-Oriented Teaching of the Natural Sciences}

The continuous decrease in enrollment in science and engineering courses prompted science educators and researchers to conduct studies on how to increase the number of enrollees in these courses. Hill et al. [10] identified seven factors thought to be involved with science career choices: teacher/counselor encouragement, participation in sciencerelated hobbies and activities, academic self-image, sciencerelated career interest, parental encouragement and support, the perceived relevance of mathematics and science, and mathematics and science ability.

In a study done by Weisgram and Bigler [11], middle school girls were exposed to presentations done by female scientists, hands-on science activities, and information about scientific careers. The study found out that girls, who believed more strongly in the altruistic value of scientific careers, scored higher on the self-efficacy and utility measures than their peers. Furthermore, belief in the altruistic value of science predicted interest in science.

Another study done by Mason and Kahle (2006) showed that a class exposed to career-oriented intervention program had significantly higher mean scores on tests of attitudes toward science, perceptions of science, extracurricular science activities, and interest in a science-related career compared to a conventional class.

\section{Performance Task as an Assessment Tool in Teaching the Natural Sciences}

Learning by doing has been the theme of science education today wherein students are presented with real life problems and students are engaged to uncover the concepts necessary to solve a problem [12] Performance task may be the appropriate tool to assess Dewey's "learning by doing."

Wisconsin Education Association Council or WEAC [13] defines performance task as an assessment requiring students to demonstrate that they have mastered specific skills and competencies by performing or producing something. Moreover, the Association for Supervision and Curriculum Development or ASCD [14] reiterated that performancebased learning represents a set of strategies for the acquisition and application of knowledge, skills, and work habits through the performance of tasks that are meaningful and engaging to students. Table 1 shows the comparison between traditional instruction and performance-based learning as stated by ASCD [14].

Performance task calls for assessments of the following skills/tasks [13]: designing and carrying out experiments; writing essays which require students to rethink, to integrate, or to apply information; working with other students to accomplish tasks; demonstrating proficiency in using a piece 
of equipment or a technique; building models; developing, interpreting, and using maps; making collections; writing term papers, critiques, poems, or short stories; giving speeches; playing musical instruments; participating in oral examinations; developing portfolios; and developing athletic skills or routines.

Rule [15] stated that authentic assessments such as a performance task should have the following characteristics: uses real-world problems that mimic the work of professionals; includes open-ended inquiry, thinking skills, and metacognition; engages students in discourse and social learning; and empowers students to direct their own learning.

Worldwide Instructional System [16] reiterated that when developing performance tasks, the following questions should be considered: who are the learners?; what do they need to achieve?; how will I know when they have achieved it?; and how will they get there?

Different studies have been done to investigate the effectiveness of performance task in the teaching and learning process. Below are selected studies.

A study done by Stahelin et al. [17] demonstrated that a biochemistry laboratory course with a project-oriented goal greatly enhanced students' scientific reasoning and understanding of the research process. In addition, evaluation of students' progress in the project-oriented task also indicated successful linkage of skill-building and studentdirected activities even for students with no prior experience.

Similarly, Albanese and Mitchell [18] conducted a metaanalysis of six (6) studies on the effects of problem-based learning $(\mathrm{PBL})$. The study established that compared with conventional instruction, $\mathrm{PBL}$ is more nurturing and enjoyable. Furthermore, PBL graduates performed well and sometimes better on clinical examinations and faculty evaluations; further, they are more likely to enter family medicine.

Performance tasks are similar to project-oriented and problem-based approaches because students are also given a problem, which they attempt to solve by developing or creating a product. Therefore, these are good assessment strategies in the teaching and learning process.

\section{Critical Thinking}

Costa [19] stated that since education is the principal means of preparing students, the future citizens, for an active and responsible life within this technologically based society, school at all levels should focus on fostering and developing critical thinking skills. Similarly, Schafersman [20] mentioned that to prepare students to succeed in life, science education must focus on developing the critical thinking skills of students.

There are different views about critical thinking. Pascarella and Terenzini [21] identified actions that are involved in critical thinking. These are identifying central issues and assumptions in an argument; recognizing important relationships; making correct inferences from data; deducing conclusions from information or data provided; interpreting whether conclusions are warranted on the basis of the data given; and evaluating evidence or authority.
In contrast, some scholars and educators erroneously assume critical thinking to be higher order thinking or cognitive processing [3]. According to Elder and Paul [22], critical thinking is the ability of thinkers to reason out their own ideas. For this reason, they should have developed sound criteria and standards for analyzing and assessing their own thinking. Hedges [23] argued that critical thinking can be set apart from problem solving, because it is a linear process of evaluation, whereas critical thinking is a comprehensive set of abilities allowing the inquirer to properly facilitate each stage of the linear problem solving process.

According to Chaffee [24], critical thinking is "our active, purposeful, and organized efforts to make sense of our world by carefully examining our thinking, and the thinking of others, in order to clarify and improve our understanding" (p. 29). Halpern [25] stated that critical thinking is "thinking that is purposeful, reasoned and goal directed. It is the kind of thinking involved, in solving problems, formulating inferences, calculating likelihoods, and making decisions" (p. 5). Simply put, critical thinking is the "reasonable and reflective thinking that is focused upon deciding what to believe or do" [26, p. 18].

Johnson [27] enumerated eleven critical thinking skills needed by students: inferring; comparing; comparing and contrasting; analyzing; supporting a statement; decision making; ordering; evaluating/critiquing; creating groups; investigating; and experiencing.

Several factors were noted to affect the critical thinking of students such as learning and teaching, learner factors, and individual and caring factors [28]. In effect, educators are encouraged to undergo training in the design and implementation of this approach to enhance the higher order critical thinking skills of students.

Almeida [29] showed how intelligence could be characterized by an integrated set of high order cognitive skills: critical thinking; questioning; and creativity. Intelligent people manifest their skills by adapting to, shaping, and selecting environments through a balance in their use of different kinds of abilities [29]. Thomas [30] said that in most universities, one of the skills they have to emphasize among their graduates is thinking critically, with the collaboration and support of a learning community that provides information, feedback, and encouragement.

Four components were noted crucial by Thomas [30] in developing critical thinking skills: evaluation and analysis; analysis and synthesis of an argument; reasoning individually and collaboratively; and self-regulation.

Similarly, Watson and Glaser [31] identified five domains crucial in developing critical thinking: inference; recognition of assumptions; deduction; interpretation; and evaluation of arguments.

Understanding these skills and properly integrating them in the learning environment is a helpful tool in producing graduates who are able to make good decisions, solve problems, and evaluate solutions effectively [30].

Different studies have been done to enhance students' critical thinking skills. Below are selected studies involving different strategies in developing critical thinking.

Understanding chemistry in its representational and symbolic nature is one of the basic skills students must have 
in order to develop critical thinking skills. Therefore, it is said that learning chemistry involves students' visual-spatial abilities that support students in performing certain cognitive operations through diagrams [32]. This study integrated casebased computerized laboratories and modeling curriculum using hands-on experiments and molecular modeling with an emphasis on scientific inquiry and case studies. Results showed that students who are subjected to this learning environment significantly improved higher order critical thinking skills of question posing, inquiry, and modeling [32]. In this era where technology offers a lot for educational purposes, students' knowledge can be enhanced in a computer-based learning environment where chemistry education can be understood better in its molecular level through models and simulations.

Mobile learning can also be used to enhance critical thinking. It has increasingly attracted the interest of educators, researchers, and companies that develop learning systems and publish instructional materials [33]. In their study, undergraduates enrolled in computer education classes improved significantly using the mobile learning system incorporating collaborative outdoor experiences through virtual communication.

Writing is another approach to develop critical thinking skills and language and learning of science as well as acquisition of scientific literacy [34]. He found out that using this approach especially in large classes resulted in a significant positive relationship between the formative and summative written assignments in general chemistry courses. The exploratory content questions designed for students to write and analyze results in their own words provided the greatest motivation for the students in large chemistry class to keep track of the material in a consistent and proactive manner. Thus, this resulted in improvement not only to their critical thinking skills but also to their study habits [34]. Quitadamo and Kurtz [35] employed a similar approach among students of general biology courses and showed that students from the writing group significantly outperformed their nonwriting peers in both total critical thinking skill and the component critical thinking skills of analysis and inference. In addition to writing, prior critical thinking skill and course instructor significantly affected critical thinking performance. Similarly, prior critical thinking skill has the largest effect on critical thinking gains. These results indicate that the process of writing helps students develop improved analytical and inferential skills. The observation that students who come to general education biology with greater critical thinking skills leave with the largest skill gains has important implications for the K-12 school system as well [35]. The results of their study reinforced the idea that students should be explicitly taught critical thinking skills and be expected to practice them as early and often as possible.

Inquiry-based learning is another approach to enhance the critical thinking skills of students. In a study conducted by Kitot [36], students' improvement in their critical thinking skills (mean difference $=.5392, t=-7347$, and 0.000 sig $=$ $P<0.05)$ could be seen before and after inquiry teaching was carried out. The dynamic nature of inquiry teaching allows students to use their imagination and thoughts to make appropriate interpretations of the acquired knowledge and questions posed by the teachers who would act as facilitators in acquiring knowledge [36].

Another approach in the development of critical thinking skills is the infusion approach. It aims at teaching specific critical thinking skills along with different study subjects and instilling critical thinking skills through teaching the set learning material [37]. Moreover, this approach helps students to apply their knowledge and evaluate real-life situations from the different lessons that they learned from the class. Aizikovitsh and Amita [38] used this approach in teaching the unit "probability in the daily life" among Israeli mathematics students, and a moderate improvement was noted in their critical thinking skills due to maturation and accumulating life experiences. Their study implies that educators should gradually switch the intellectual development of the student beyond the technical content of the course by creating learning environments that foster critical thinking and which will, in turn, encourage the students to investigate the issue at hand, evaluate the information, and react to it as a critical thinker.

Quing [39] suggested the task-based learning (TBL) to be another approach in developing critical thinking skills. It is somewhat similar to problem-based learning where students are provided with rich learning opportunities and real-life tasks and problems as teaching materials to stimulate students to think. In their study conducted in the Chinese Middle School, students exposed to task-based learning environment in their chemistry laboratory class significantly improved their critical thinking dispositions. The study further suggested that the use of task-based learning model in chemistry class is an effective way for teachers to enhance students' critical thinking disposition, focusing on their analytical and systematic skills, self-confidence, and maturity.

Quitadamo and Kurtz [40] conducted a study on peerled team learning to examine its impact on critical thinking gains in science and mathematics courses at a research university in the Pacific Northwest. Peer-led team learning was first developed by Woodward et al. [41] as an integrated method that promoted discourse and creative problem solving in chemistry at the City College of New York. It is characterized by a cohort-based social learning structure whereby trained undergraduates or "peer leaders" who have successfully completed the course and have been trained in small group dynamics and learning theory [40] guided 48 less experienced peers toward conceptual understanding through group-focused science and math problem solving [42-45]. In this study, peer-led team learning appeared to help underperforming students make positive gains in critical thinking skills which resulted in the improvement grade performance and retention skills in science and math courses, particularly for females. Therefore, Quitadamo and Kurtz [40] suggested that instructor commitment to peer-led team learning played an important role while successful implementation was achieved due to well-trained peer leaders and committed faculty who believe in the method. This calls for a continued and in-depth implementation of this learning method having its potential to improve undergraduate 


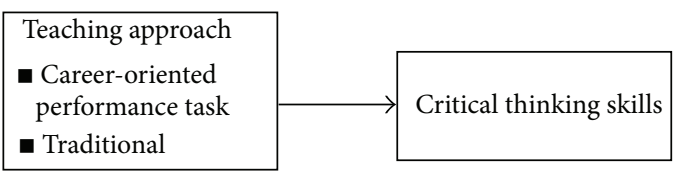

Figure 1: Conceptual framework of the study.

critical thinking skills especially in science and mathematics courses.

Rational decision making based on evaluative or critical thinking is becoming more vital among students towards scientific literacy. Therefore, it is a must among learners to be prepared to question truisms, raise doubts, investigate situations, and probe alternatives (i.e., think critically) in the context of both schooling and daily life [46]. Along with this principle, a longitudinal study conducted by Miri et al. [46] suggested that if teachers purposely and persistently practice higher order thinking strategies such as dealing in class with real-world problems, encouraging open-ended class discussions, and fostering inquiry-oriented experiments, there is a good chance for a consequent development of critical thinking capabilities. Critical thinking skills of students depend on some variables such as learning environment, the social structure of learning environment, and the teaching style of the teacher [47]. As such, course contents and teaching strategies must be recognized, and students must be challenged to apply problem solving and critical thinking into their real lives [48]. Therefore, it is imperative that professional development programs for educators can be directed towards a structured and a better understanding of what higher order thinking skills are, to be able to conceptualize critical thinking in a more rational way. Evidences of this study showed that if the teacher knowingly, persistently, and purposely teaches promoting higher order thinking among her/his students, there are good chances for success [46].

Thus, critical thinking is an essential tool in producing productive citizens and should be developed in all areas of study, most especially in science education.

\section{Conceptual Framework}

In the light of the literatures presented, Figure 1 shows the conceptual framework of the study.

The conceptual framework of the study shows how the career-oriented performance task and the traditional approach would affect students' critical thinking skills.

This study aims at comparing students exposed to careeroriented performance task (COPT) approach and students exposed to the traditional teaching approach (TTA) in terms of their effect on students' critical thinking skills. Hernandez [49] reiterated that critical thinking sharpens students' capacity to distinguish between fact and opinion, present his thoughts and ideas clearly and logically, and even argue them in a compelling manner. The positive outcomes of enhancing critical thinking skills prompted the researcher to use the variable in connection to COPT.
TABLE 2: WGCTA split half reliability coefficient.

\begin{tabular}{lcc}
\hline Subtests & $\begin{array}{c}\text { Number of } \\
\text { items }\end{array}$ & $\begin{array}{c}\text { Reliability coefficient } \\
\text { corrected by } \\
\text { Spearman-Brown } \\
\text { formula }\end{array}$ \\
\hline Inference & 20 & 0.61 \\
Recognition of assumption & 16 & 0.74 \\
Deduction & 25 & 0.53 \\
Interpretation & 24 & 0.67 \\
Evaluation of arguments & 15 & 0.62 \\
\hline
\end{tabular}

Source: [31].

\section{Research Hypothesis}

Students exposed to career-oriented performance task (COPT) approach have higher critical thinking skills than those students exposed to the traditional teaching approach (TTA).

\section{The Sample}

The samples were two intact heterogeneous sections of seventy-seven (77) first-year college students of a private tertiary institution taking up general inorganic chemistry course. The study was conducted during the prefinal grading period of second semester, school year 2011-2012. The assignment of the COPT class and the TTA class was randomly selected by tossing a coin. Section CHM1B class was assigned to be the COPT class, while section CHM1A class was assigned to be the TTA class.

Thirty-seven (37) students from CHM1A and thirtynine (39) students from CHM1B took the pretest, while thirty-eight (38) students from CHM1A and thirty-seven (37) students from CHM1B took the posttest. A total of seventysix (76) students took the pretest while seventy-five (75) took the posttest.

\section{The Instrument}

The Watson-Glaser Critical Thinking Appraisal is one of the most popular standardized tests used in measuring critical thinking skills. The instrument was developed by Watson and Glaser in 1964 [31]. The WGCTA is a paper-and-pencil test consisting of one hundred (100) items divided into the five critical thinking domains, namely, inference, recognition of assumptions, deduction, interpretation, and evaluation of arguments. The test items 1 to 20 measure the inference domain, 21 to 36 assess the recognition of assumption, 37 to 61 assess deduction, 62 to 85 assess interpretation, and 86 to 100 assess the evaluation of arguments. Table 2 shows the split half reliability coefficient of the Watson-Glaser Critical Thinking Appraisal.

\section{Intervention}

9.1. Career-Oriented Performance Task Approach. The COPT class utilized the usual routine in teaching and learning 
process, namely, motivation, lesson proper, generalization, and assessment.

Orientation regarding the career-oriented performance tasks that the students need to accomplish and submit at the end of each topic was done before the start of discussion.

The motivation stage made use of presenting different careers or professions stipulated in the COPT in addition to the usual games, demonstrations, simulations, and predictobserve-explain or POE activities.

The lesson proper stage made use of cooperative or group learning, hands-on and laboratory activities, small group discussion, reflective thinking, think-aloud technique, and inquiry and discovery learning to increase participation among students using researcher-made worksheets and activity sheets.

The generalization stage made use of group presentations aside from the usual summary of the lesson.

The assessment stage made use of the career-oriented performance task aside from the usual seatworks, quizzes, and long tests. Since the COPT was given even before the discussion on a certain topic commences, students had about two weeks to accomplish the task at their free time.

A separate meeting was devoted to the presentation of COPT outputs per group. This was done when the topic covered in the COPT had been discussed already.

A career-oriented performance task is a researcher-made set of performance tasks, which aims to integrate careeroriented examples and inquiry-based activities in selected topics in chemistry. The selected topics were the ones covered in the prefinal grading period of the general inorganic chemistry. These were gases, liquids, solids solutions, and colloids. For each topic, three different career-oriented performance tasks were prepared.

The COPT has the following parts: the purpose, which is the objective or what is intended to be achieved after doing the task; the task, which focuses on the career or profession that is being connected to chemistry concepts; the addressees, which is the intended readers or viewers of the product; the setting, which is the project's problem; the output, which is the required product in the project; and the norm which is the basis for grading the project.

Example of the career presented in the COPT under the topic gases is SCUBA diving instructor. Students need to create a pamphlet manual that will explain the diving rules to prevent divers to suffer from "bends," air embolism, and oxygen toxicity. These are derived from the gas laws, such as Boyle, Charles, Dalton, and Henry's laws. Outputs were graded according to creativity, organization, completeness, and content.

9.2. Traditional Teaching Approach. The TTA class was exposed to the usual routine in teaching, namely, motivation, lesson proper, generalization, and assessment. The motivation stage made use of games and demonstrations; the lesson proper stage used lecture discussion; the generalization part involved summary of the lesson; and the assessment part focused on seatworks and quizzes. The teacher is the doer of the action for most of the time.
Table 3 shows a sample learning plan showing the difference between the COPT and TTA classes.

\section{Data Collection Procedure}

Two intact classes were utilized in the study. One group used the career-oriented performance tasks (COPT) while the other group used the Traditional Teaching Approach (TTA). The researcher handled both classes so that the same lessons, quizzes, and assignments were carried out and that the two groups differ only in the use of COPT. To ensure that there was no teacher bias, another chemistry faculty member observed the researcher twice in the COPT class and twice in the TTA class. A total of four (4) observations were done by the observer. The observations were conducted while the two groups were discussing the same topics.

Prior to the treatment, pretest in Watson-Glaser Critical Thinking Appraisal was given to both groups. One group was exposed to career-oriented performance tasks (COPT) while the other group to traditional teaching approaches. Posttest in Watson-Glaser Critical Thinking Appraisal was given simultaneously to both groups to eliminate possible threats to validity such as place and time.

\section{Results and Discussion}

A two-tailed independent-samples $t$-test was conducted to compare the pretest scores of COPT and TTA classes on the Watson-Glaser Critical Thinking Appraisal (WGCTA). Table 4 shows that there is no significant difference in the critical thinking skills pretest scores of the COPT $(\mathrm{M}=49.6$, $\mathrm{SD}=4.83)$ and the TTA classes $(\mathrm{M}=49.1, \mathrm{SD}=3.56)$; $t(74)=0.520, P=0.605$. These results suggest that the COPT and the TTA students' critical thinking skills were comparable prior to intervention.

A one-tailed independent-samples $t$-test was conducted to compare the posttest scores of COPT and TTA students on the Watson-Glaser Critical Thinking Appraisal (WGCTA).

Table 5 shows that there is no significant difference in the posttest mean scores in the WGCTA of COPT $(\mathrm{M}=53.1$, $\mathrm{SD}=8.31)$ and TTA $(\mathrm{M}=52.4, \mathrm{SD}=6.53), t(73)=0.352$, $P=0.363$. This result suggests that the critical thinking skills of students who were taught using COPT and those who were exposed to TTA were comparable even after intervention.

The results contradict the findings of Akporehwe and Onwioduokit [6] that activity-based approaches, such as the COPT, significantly enhance students' critical thinking and scientific attitudes. Similarly, the result of the study is also in contradiction to the findings of House [9] that career-oriented classroom instructional activities increase the interest in science career among students in Korea.

There is a possibility that one-grading period in a semester length of exposure to the intervention was not sufficient to produce significant difference between the critical thinking skills of the COPT and the TTA students. Furthermore, after the presentation of COPT outputs, the teacher-researcher did not conduct postdiscussion or feedback on the outputs of the students due to limited time. Results of a study done 
TABLE 3: Learning plan comparison between the COPT and TTA classes on the topic gas laws.

\begin{tabular}{|c|c|}
\hline COPT & TTA \\
\hline 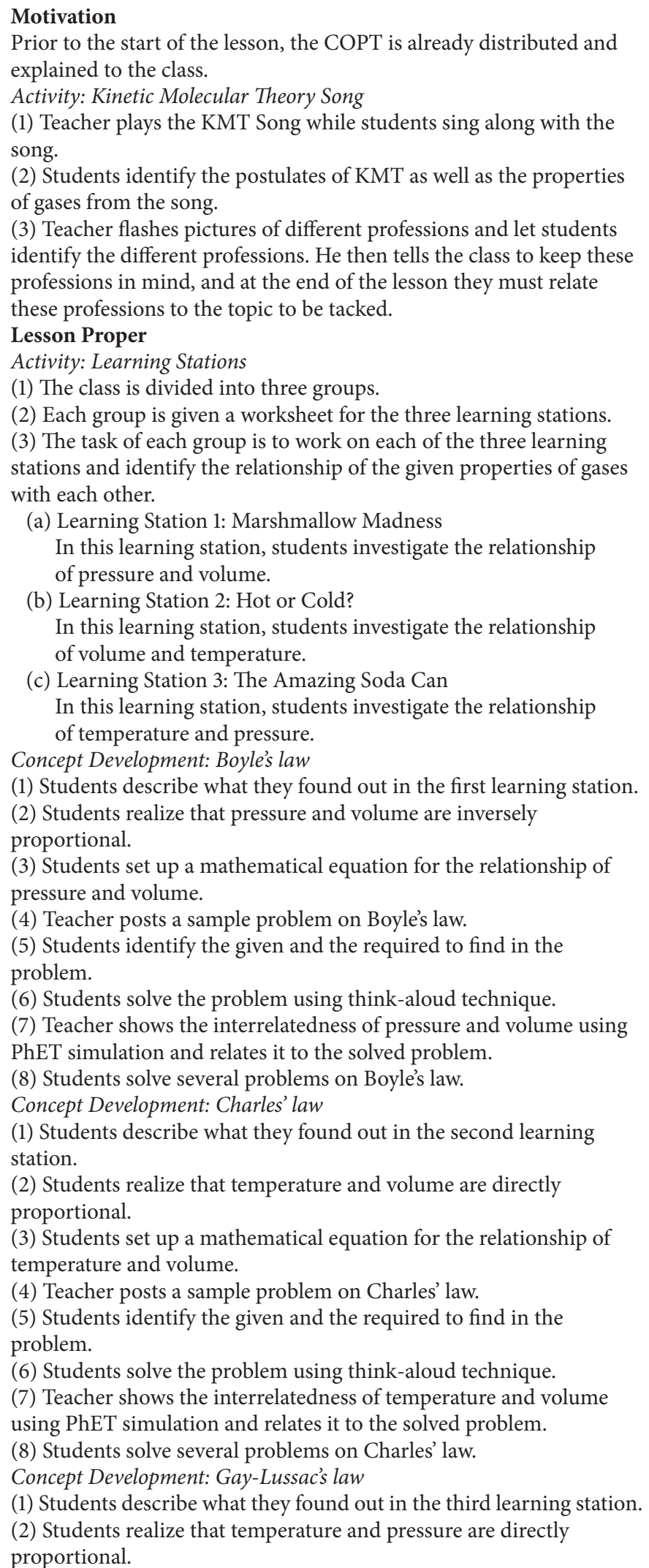 & $\begin{array}{l}\text { Motivation } \\
\text { Activity: Kinetic Molecular Theory Song } \\
\text { (1) Teacher plays the KMT Song while students sing along with } \\
\text { the song. } \\
\text { (2) Students identify the postulates of KMT as well as the } \\
\text { properties of gases from the song. } \\
\text { Lesson Proper } \\
\text { Concept Development: Boyle's law } \\
\text { (1) Teacher shows the mathematical equation of Boyle's law. } \\
\text { (2) Students realize that pressure and volume are inversely } \\
\text { proportional. } \\
\text { (3) Teacher posts a sample problem on Boyle's law. } \\
\text { (4) Students identify the given and the required to find in the } \\
\text { problem. } \\
\text { (5) Teacher shows how to solve the problem. } \\
\text { (6) Students solve several problems on Boyle's law. } \\
\text { Concept Development: Charles' law } \\
\text { (1) Teacher shows the mathematical equation of Charles' law. } \\
\text { (2) Students realize that temperature and volume are directly } \\
\text { proportional. } \\
\text { (3) Teacher posts a sample problem on Charles' law. } \\
\text { (4) Students identify the given and the required to find in the } \\
\text { problem. } \\
\text { (5) Teacher shows how to solve the problem. } \\
\text { (6) Students solve several problems on Charles' law. } \\
\text { Concept Development: Gay-Lussac's law } \\
\text { (1) Teacher shows the mathematical equation of Gay-Lussac's } \\
\text { law. } \\
\text { (2) Students realize that temperature and pressure are directly } \\
\text { proportional. } \\
\text { (3) Teacher posts a sample problem on Gay-Lussac's law. } \\
\text { (4) Students identify the given and the required to find in the } \\
\text { problem. } \\
\text { (5) Teacher shows how to solve the problem. } \\
\text { (6) Students solve several problems on Gay-Lussac's law. } \\
\text { Concept Development: Combined Gas law } \\
\text { (1) Teacher shows the equation for combined gas law as well as a } \\
\text { problem on about it. } \\
\text { (2) Students identify the given and the required to find the } \\
\text { problem. } \\
\text { (3) Teachers show how to solve the problem. } \\
\text { (4) Students solve several problems on combined gas law. } \\
\text { Generalization/Synthesis } \\
\text { Students enumerate the different gas laws as well as the } \\
\text { equations for them. } \\
\text { Board work, seatwork, quiz }\end{array}$ \\
\hline
\end{tabular}


TABle 3: Continued.

COPT TTA

(3) Students set up a mathematical equation for the relationship of temperature and pressure.

(4) Teacher posts a sample problem on Gay-Lussac's law.

(5) Students identify the given and the required to find in the problem.

(6) Students solve the problem using think-aloud technique.

(7) Teacher shows the interrelatedness of temperature and pressure using PhET simulation and relates it to the solved problem.

(8) Students solve several problems on Gay-Lussac's law.

Concept Development: Combined Gas Law

(1) Students derive the equation for the combined gas law using the mathematical relationship of the three basic gas laws, namely, Boyle's, Charles', and Gay-Lussac's.

(2) Teacher shows a problem on combined gas law.

(3) Students identify the given and the required to find out the problem.

(4) Students solve the problem using the think-aloud technique.

(5) Teacher shows the interrelatedness of temperature, pressure, and volume using PhET simulation and relates it to the solved problem.

(6) Students solve several problems on combined gas law.

Generalization/Synthesis

(1) Using the same group, students do a mind map on the properties of gases and gas laws.

(2) Students relate the different gas laws to the professions flashed at the beginning of the lesson.

(3) Students present their COPT outputs.

Assessment

Boardwork, seatwork, quiz, mindmap (gas laws), career-oriented performance task

TABLE 4: Independent-samples $t$-test on critical thinking skills pretest.

\begin{tabular}{lcccccc}
\hline Group & $N$ & Mean & SD & $t$ & df & $P$ \\
\hline COPT & 39 & 49.6 & 4.83 & 0.520 & 74 & 0.605 \\
TTA & 37 & 49.1 & 3.56 & & &
\end{tabular}

${ }^{*} P<0.05$.

TABLE 5: Independent-samples $t$-test on critical thinking skills posttest.

\begin{tabular}{lcccccc}
\hline Group & $N$ & Mean & SD & $t$ & df & $P$ \\
\hline COPT & 37 & 53.1 & 8.31 & \multirow{2}{*}{0.352} & 73 & 0.363 \\
TTA & 38 & 52.4 & 6.53 & & & \\
\hline
\end{tabular}

${ }^{*} P<0.05$.

by Richardson et al. [50] show that peer feedback strategy in online teaching impacted student's higher cognitive skill such as critical thinking both for receivers and providers of peer feedback. Similarly, a study done by MacKnight [51] about online discussions shows that giving feedback to her students fosters the development of critical thinking skills. Furthermore, Pandey [52] found out that feedback in group discussions among nursing students enhanced their critical thinking skills.

It is also possible that during the day of presentation, students were exposed to too much information since ten (10) groups have presented their outputs. Output presentation is scheduled for one meeting only due to time constraint. Students were asked to present their COPT outputs thrice for the duration of the study. Bullen [53] cited in his study that overload in information has a negative impact on the development of student's critical thinking skills, most especially those who were not able to develop a good study habit. In addition, Bawden and Robinson [54] mentioned in their study that taking control of one's information environment improves information management which includes time management, desk management, critical thinking, information presentation, better information organization, and cultivation of a rational personal information management style.

Postdiscussion or feedback on the COPT outputs should have been done by the teacher-researcher right after every presentation to address misconceptions and to applaud correct assumptions. Moreover, the presentation should not have been congested to a single period only, to facilitate better absorption and in-depth understanding of concepts. In addition, the COPT could have been spread to cover most of the topics in chemistry.

Also, Abrami et al. [55] mentioned in their study that the critical thinking skill being developed should be explicitly stated in the intervention's objectives. In the design of the COPT, the critical thinking skills were not stated in the objectives. Therefore, it is imperative that the critical thinking skill should be stated in the intervention's objectives so 
that the researcher would know what to expect after its implementation.

\section{Conclusions and Recommendations}

The integration of career-oriented examples in chemistry was not effective in enhancing students' critical thinking skills given the limited time of intervention. Longer exposure to intervention is necessary to enhance college students' critical thinking skills.

For future researchers in chemistry education and science education, investigate the effectiveness of the COPT in terms of not only the student's critical thinking skills but also the students' achievement, conceptual understanding, problem solving skills, decision making skills, and self efficacy. In addition, improve some aspects of the implementation of career-oriented performance task such as investigate the effects of COPT after two or three grading periods or one semester of a school year to ensure that ample time will be devoted to the application of the intervention to test whether this will produce significant effect on critical thinking skills; investigate the effects of postdiscussion feedback on the COPT outputs right after every presentation to test whether this will produce significant effect on critical thinking or not; and investigate the effects of doing the COPT activity during class hours to test if this will produce significant effect on critical thinking or not; and investigate the effects of COPT in high school setting to test whether this will produce significant effect on critical thinking or not. Another recommendation is to check the attribute-treatment interaction, whether the intervention is suitable for that group or sample or not.

\section{References}

[1] J. Lapus, “DepEd: NAT results show steady improvement," 2009, http://www.abs-cbnnews.com/nation/youth/09/03/09/depednat-results-show-steady-improvement.

[2] M. O. Martin, I. V. S. Mullis, E. J. Gonzales, K. D. Gregory, T. A. Smith, and S. J. Chrostowski, TIMSS 2003: International Science Report; Findings from IEA'S Report of the Trends in International Mathematics and Science Study, The International Study Center, Lynch School of Education, Boston College, Chestnut Hill, Mass, USA, 2004.

[3] R. Paul and M. Scriven, "Critical thinking as defined by the national council for excellence in critical thinking," in Proceedings of the 8th Annual International Conference on Critical Thinking and Education Reform, 1987.

[4] L. Elder, "Our Concept and Definition of Critical Thinking," 2007, http://www.criticalthinking.org/pages/our-concept-of-cr itical-thinking/411.

[5] N. W. Brickhouse and C. S. Carter, "What makes chemistry difficult? Alternate perceptions," Journal of Chemical Education, vol. 66 , no. 3, pp. 223-225, 1989.

[6] J. N. Akporehwe and F. A. Onwioduokit, "Enhancing scientific attitudes through activity-based approcahes," Nigerian Journal of Science and Science Education, vol. 8, no. 2, 2010.

[7] National Academy of Science, "Strengthening High School Chemistry Education Through Teacher Outreach Programs: A Workshop Summary to the Chemical Sciences Roundtable,"
2009, http://www.nap.edu/openbook.php?record_id=12533\& page $=9$.

[8] L. H. Barrow and K. A. Phillips, "Science career interests among high school females one year after participation in a summer science program," National Science Foundation Grant NSF HRD96-19140.

[9] J. D. House, "Classroom instructional strategies and science career interest for adolescent students in Korea: results from the TIMSS, 2003 assessment," Journal of Instructional Psychology, vol. 36, no. 1, 2009.

[10] O. W. Hill, W. C. Pettus, and B. A. Hedin, "Three studies of factors affecting the attitudes of blacks and females toward the pursuit of science and science-related careers," Journal of Research in Science Teaching, vol. 27, no. 4, pp. 289-314, 2006.

[11] E. S. Weisgram and R. S. Bigler, "Girls and science careers: the role of altruistic values and attitudes about scientific tasks," Journal of Applied Developmental Psychology, vol. 27, no. 4, pp. 326-348, 2006.

[12] J. Dewey, Democracy and Education, Free Press, New York, NY, USA, 1966.

[13] Wisconsin Education Association Council or WEAC, "Teaching for Understanding: Educating Students for Performance," 1996, http://www.weac.org/News_and_Publications/education_ news/1996-1997/under.aspx.

[14] Association for Supervision and Curriculum Development, The Common Sense of Differentiation: Meeting Specific Learner Needs in the Regular Classroom, ASCD, Alexandria, VA, USA, 2005.

[15] C. Rule, “Authentic Assessment," 2006, http://wik.ed.uiuc.edu/ index.php/Authentic_Assessment/.

[16] Worldwide Instructional System, "Performance Assessment in Online Learning," in Proceedings of the 19th Annual Conference on Distance Teaching and Learning, 2005.

[17] R. V. Stahelin, R. E. Forslund, D. J. Wink, and W. Cho, "Development of a biochemistry laboratory course with a projectoriented goal," Biochemistry and Molecular Biology Education, vol. 31, no. 2, pp. 106-112, 2003.

[18] M. A. Albanese and S. Mitchell, "Problem-based learning: a review of literature on its outcomes and implementation issues," Academic Medicine, vol. 68, no. 1, pp. 52-81, 1993.

[19] A. L. Costa, Developing Minds: A Resource Book for Teaching Thinking, Association for Supervision and Curriculum Development, Alexandria, VA, USA, 1985.

[20] S. D. Schafersman, "An Introduction to Critical Thinking," 1991, http://www.anintroductiontocriticalthinking.htm.

[21] E. Pascarella and P. Terenzini, How College Affects Students: Findings and Insights from Twenty Years of Research, Jossey Bass, San Francisco, Calif, USA, 1991.

[22] L. Elder and R. Paul, "Critical Thinking: why we must transform our teaching," Journal of Developmental Education, vol. 18, no. 1, pp. 34-35, 1994.

[23] L. E. Hedges, Helping Students Develop Thinking Skills Through the Problem-Solving Approach to Teaching, The Ohio State University, 1991.

[24] J. Chaffee, Thinking Critically, Houghton Mifflin, Boston, Mass, USA, 1988.

[25] D. F. Halpern, Thought and Knowledge: An Introduction to Critical Thinking, Lawrence Earlbaum Associates, Hillsdale, NJ, USA, 1989.

[26] S. P. Norris and R. H. Ennis, Evaluating Critical Thinking. Teaching Thinking. R. J. S. D. N. Perkins, Midwest Publications, Pacific Grove, Calif, USA, 1989. 
[27] R. H. Johnson, Manifest Rationality: A Pragmatic Theory of Argument, Lawrence Erlbaum Associates, Mahwah, NJ, USA, 2000.

[28] N. Mahapoonyanont, "Factors related to critical thinking abilities, a meta-analysis," Procedia Social and Behavioral Sciences, vol. 9, pp. 986-990, 2010.

[29] P. Almeida, "Critical thinking, questioning and creativity as components of ntelligence," Procedia-Social and Behavioral Sciences, vol. 30, pp. 357-362, 2011.

[30] T. Thomas, "Developing first year students' critical thinking skills," Asian Social Science, vol. 7, no. 4, 2011.

[31] G. Watson and E. Glaser, Watson-Glaser Critical Thinking Appraisal, Harcourt Brace Jovanovich, New York, NY, USA, 1964.

[32] Z. Kabernan and Y. J. Dori, Metacognition in Chemical Education: Question Posing in the Case-Based Computerized Learning Environment, Technion-Israel Institute of Technology, 2008.

[33] N. Cavus and H. Uzunboylu, "Improving critical thinking skills in mobile learning," Procedia Social and Behavioral Sciences, vol. 1, pp. 434-438, 2009.

[34] S. Lavieri, "Using formative writing assignments to enhance student learning in a first year chemistry class," in Proceedings of the 6th WSEAS International Conference on Education and Educational Technology, pp. 21-23, Venice, Italy, November 2007.

[35] I. J. Quitadamo and M. J. Kurtz, "Learning to improve: using writing to increase critical thinking performance in general education biology," CBE Life Sciences Education, vol. 6, no. 2, pp. 140-154, 2007.

[36] A. K. A. Kitot, A. R. Ahmad, and A. A. Seman, "The effectiveness of inquiry teaching in enhancing students' critical thinking," Procedia-Social and Behavioral Sciences, vol. 7, pp. 264-273, 2010.

[37] R. Swartz, "Critical thinking, the curriculum, and the problem of transfer," in Thinking: The 2nd International Conference, D. Perkins, J. Bishop, and J. Lochhead, Eds., pp. 261-284, Erlbaum, Hillsdale, NJ, USA, 1992.

[38] E. Aizikovitsh and M. Amita, "Evaluating an infusion approach to the teaching of critical thinking skills through mathematics," Procedia Social and Behavioral Sciences, vol. 2, no. 2, pp. 38183822, 2010.

[39] Z. Quing, "Developing critical thinking disposition by taskbased learning in chemistry experiment teaching," ProcediaSocial and Behavioral Sciences, vol. 2, pp. 4561-4570, 2010.

[40] I. J. Quitadamo, "Peer-led team learning: a prospective method for increasing critical thinking in undergraduate science courses," Science Educator, vol. 18, no. 1, 2009.

[41] A. Woodward, D. K. Gosser, and M. Weiner, "Problem solving workshops in general chemistry," Journal of Chemical Education, vol. 70, no. 8, pp. 651-652, 1993.

[42] M. S. Cracolice and J. C. Deming, "Peer-led team learning," Science Teacher, vol. 68, no. 1, pp. 20-24, 2001.

[43] D. K. Gosser, A. E. Dreyfuss, D. Bozzone, O. Buka, C. Chukuigwe, and P. Varma-Nelson, "Peer Led Team Learning: The PLTL workshop model," 2003, http://www.sci.ccny.cuny.edu/ chemwksp/index.html.

[44] D. K. Gosser and V. Roth, "The workshop chemistry project: peer-led team learning," Journal of Chemical Education, vol. 75, no. 2, pp. 185-187, 1998.

[45] K. S. Lyle and W. R. Robinson, "A statistical evaluation: peerled team learning in an organic chemistry course," Journal of Chemical Education, vol. 80, no. 2, pp. 132-134, 2003.
[46] B. Miri, B. C. David, and Z. Uri, "Purposely teaching for the promotion of higher-order thinking skills: a case of critical thinking," Research in Science Education, vol. 37, no. 4, pp. 353369, 2007.

[47] C. J. Brahler, I. J. Quitadamo, and E. C. Johnson, "Student critical thinking is enhanced by developing exercise prescriptions using online learning modules," American Journal of Physiology, vol. 26, no. 1-4, pp. 210-221, 2002.

[48] S. Emir, "Education faculty students'critical thinking disposition according to academic achievement," Procedia Social and Behavioral Sciences, vol. 1, pp. 2466-2469, 2009.

[49] B. Hernandez, "Philippine Daily Inquirer," Commentary Critical Thinking, 2009, http://opinion.inquirer.net/inquireropinion/ columns/view/20090919-225907/Critical-thinking.

[50] J. C. Richardson, P. A. Ertmer, J. D. Lehman, and T. J. Newby, "Using peer feedback in online discussions to improve critical thinking," in The Annual Meeting of the Association for Educational Communications and Technology, M. Simonson, Ed., Anaheim, Calif, USA, 2007.

[51] C. MacKnight, "Teaching critical thinking through online discussions," Educause Quarterly, vol. 4, pp. 38-41, 2000, http://net .educause.edu/ir/library/pdf/EQM0048.pdf.

[52] K. Pandey, Critical thinking in Nursing. Buzzle, 2011, http:// www.buzzle.com/articles/critical-thinking-in-nursing.html.

[53] M. Bullen, "Participation and critical thinking in online university distance education," Journal of Distance Education/Revue de Lenseignement à Distance, vol. 13, no. 2, pp. 1-32, 1998.

[54] D. Bawden and L. Robinson, "The dark side of information: overload, anxiety and other paradoxes and pathologies," Journal of Information Science, vol. 35, no. 2, pp. 180-191, 2009.

[55] P. C. Abrami, R. M. Bernard, E. Borokhovski et al., "Instructional interventions affecting critical thinking skills and dispositions: a stage 1 Meta-Analysis," Review of Educational Research, vol. 78, no. 4, pp. 1102-1134, 2008. 

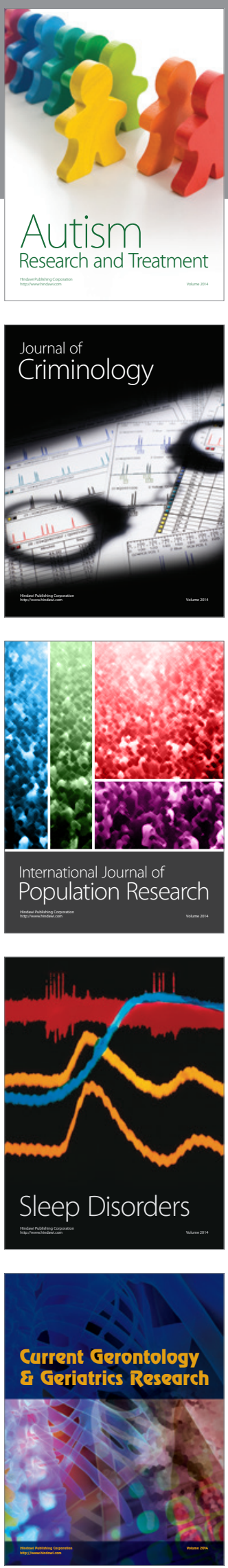
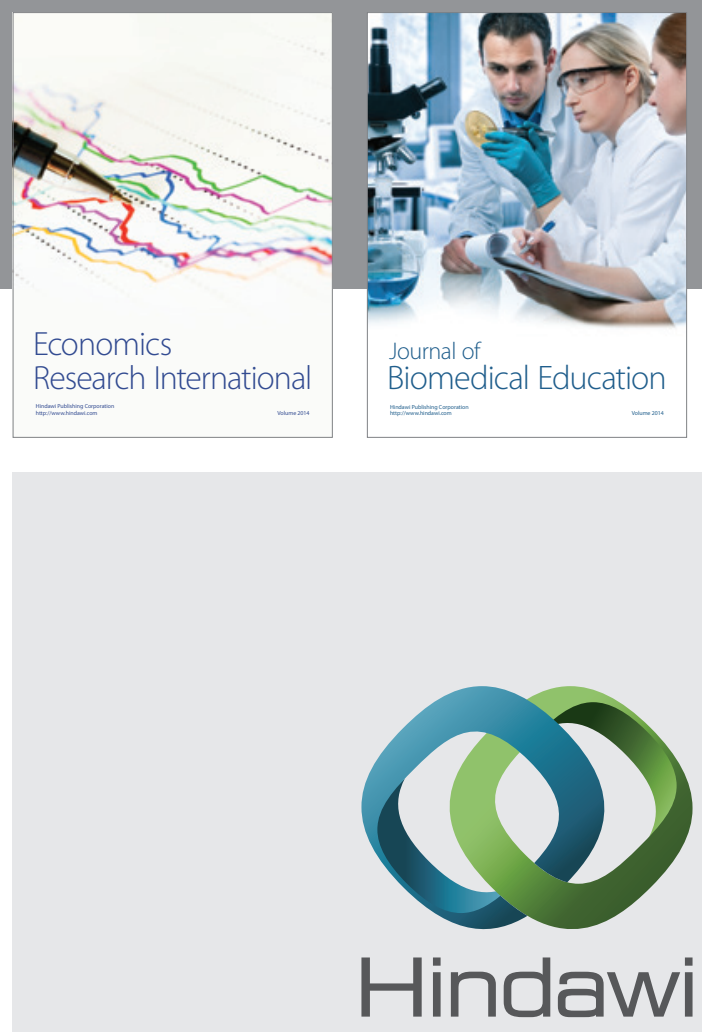

Submit your manuscripts at

http://www.hindawi.com
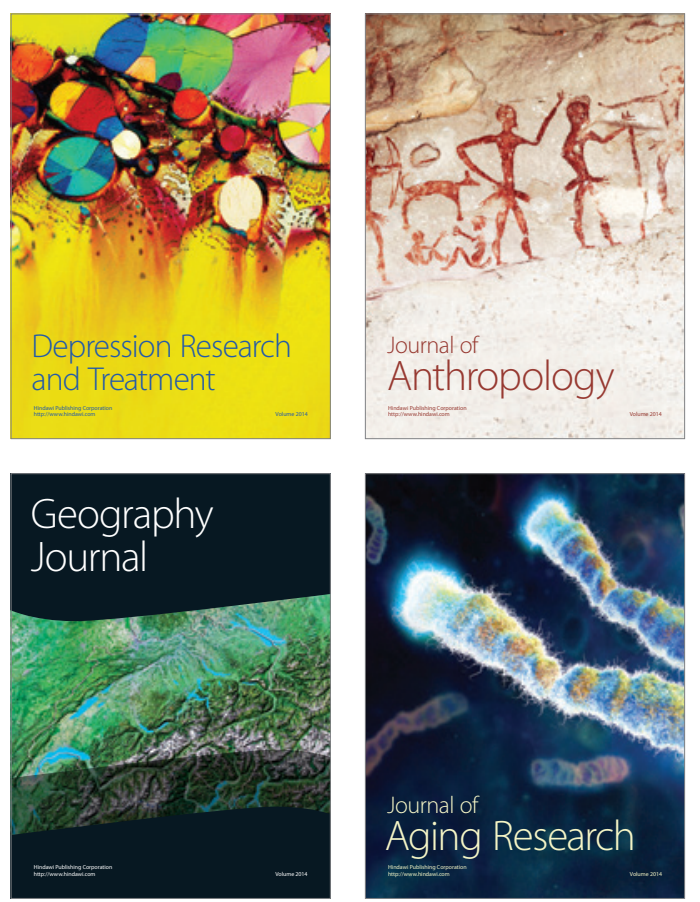
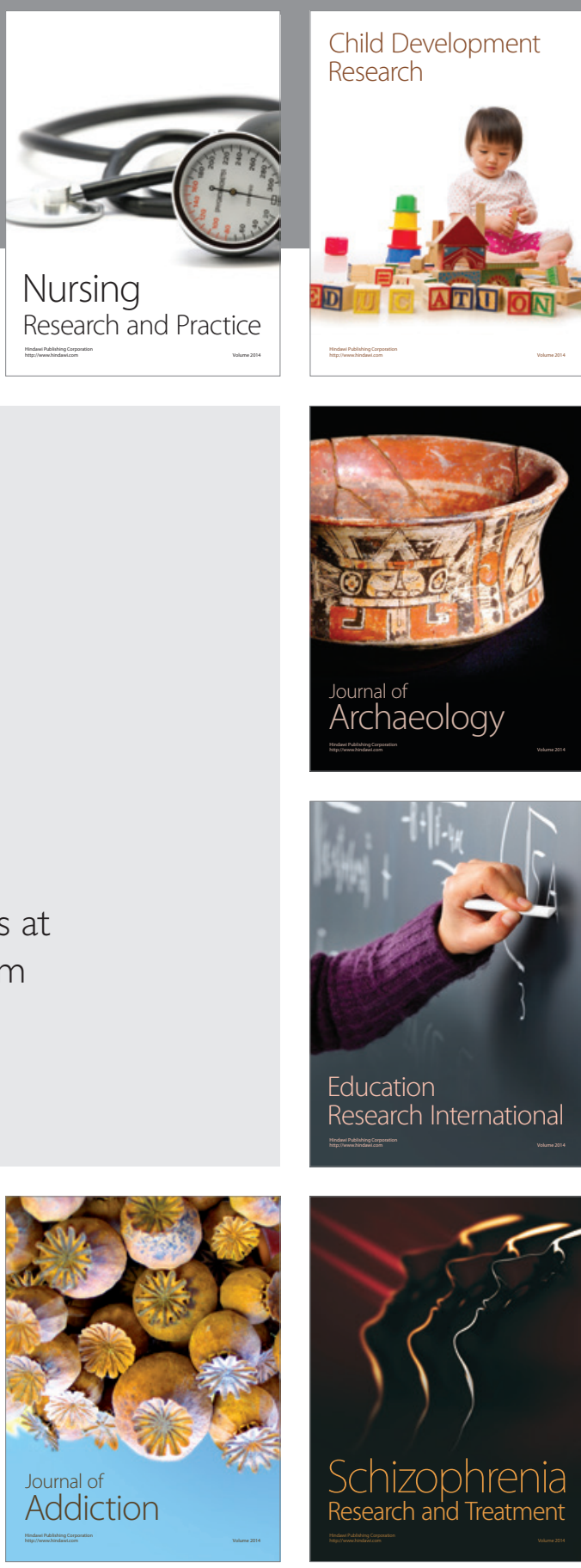

(D)
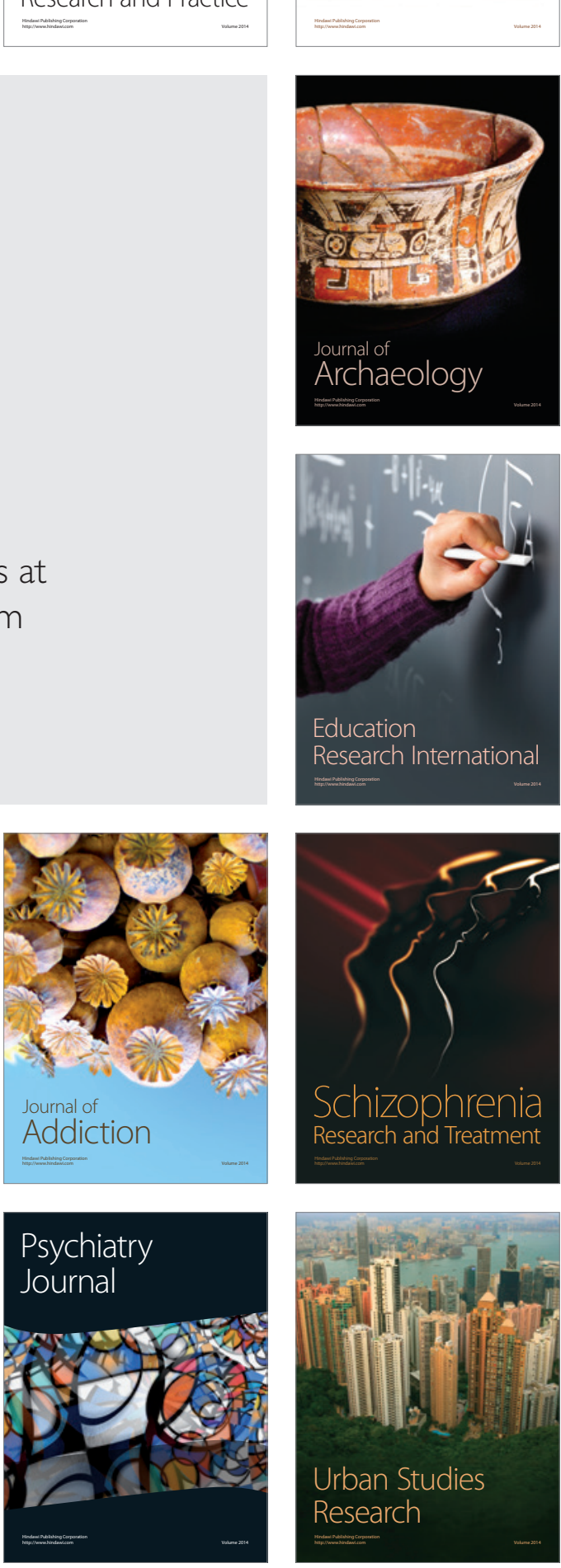